\title{
TEKNIK PEMANENAN AIR HUJAN (RAIN WATER HARVESTING) SEBAGAI ALTERNATIF UPAYA PENYELAMATAN SUMBERDAYA AIR DI WILAYAH DKI JAKARTA
}

\author{
Budi Harsoyo ${ }^{1}$
}

\begin{abstract}
Jakarta as a metropolitan city has many complex issues related to the problem of water resources crisis. Rain water harvesting techniques has become an important part in the global environmental agenda water resources management in order to overcome inequality of water in the rainy and dry (lack of water), lack of clean water supply community world, as well as flood prevention and drought. This paper tries to analyze the descriptive induction related to the theme of rain water harvesting techniques, starting with a description of the open view and the data was collected from literatures relating to the themes and issues of water resources in Jakarta area, then conducted further analysis and conclusions drawn are associated with the aspect of water conservation and water resources crisis management in DKI Jakarta.
\end{abstract}

\section{Intisari}

\begin{abstract}
Jakarta sebagai kota metropolitan memiliki masalah yang kompleks yang berhubungan dengan masalah krisis sumber daya air. Teknik pemanenan air hujan telah menjadi bagian penting dalam agenda pengelolaan sumber daya air dalam rangka untuk mengatasi ketimpangan air pada kurangnya hujan dan kekeringan (kekurangan air), pasokan air bersih masyarakat dunia, serta penanggulangan banjir dan kekeringan. Tulisan ini mencoba untuk menganalisis induksi deskriptif terkait dengan tema teknik pemanenan air hujan, dimulai dengan deskripsi dari pandangan terbuka dan data yang dikumpulkan dari literatur yang berkaitan dengan tema dan isu-isu sumber daya air di wilayah Jakarta, kemudian dilakukan analisis lebih lanjut dan kesimpulan yang diambil adalah terkait dengan aspek konservasi air dan pengelolaan sumber daya air krisis di DKI Jakarta.
\end{abstract}

Keywords: rain water harvesting, lack of water, water resource management

\section{PENDAHULUAN}

Sebagai Ibukota Negara Repubik Indonesia, Kota Jakarta mengalami perkembangan pembangunan yang luar biasa pesat dari tahun ke tahun. Kota metropolitan Jakarta selain sebagai pusat pemerintahan juga merupakan pusat segala aktivitas ekonomi, industri, perdagangan dan sosial. Dengan segala kelengkapan fasilitasnya, Kota Jakarta selalu menjadi daya tarik bagi kaum urban, baik yang hanya untuk sekedar mencari aktifitas keseharian maupun bagi pendatang dari luar daerah yang datang untuk tinggal menetap. Akibatnya jumlah penduduk Kota Jakarta semakin bertambah padat dari waktu ke waktu.

Jumlah penduduk DKI Jakarta berdasarkan data dari Dinas Kependudukan dan Catatan Sipil Propinsi DKI Jakarta per bulan Januari 2009

\footnotetext{
${ }^{1}$ Peneliti Pertama UPT Hujan Buatan BPP Teknologi,

Jalan MH. Thamrin no. 8, Gd.I Lt.19, Jakarta Pusat

E-mail : buhar04@yahoo.com
}

adalah sebanyak 8,5 juta jiwa (Tabel 1), dan pada siang hari angka tersebut akan bertambah seiring datangnya para pekerja dari kota satelit seperti Bekasi, Tangerang, Bogor, dan Depok. Bila dikaitkan dengan beban utilitas perkotaan, jumlah total penduduk yang harus dilayani untuk pemenuhan kebutuhan dasarnya bisa mencapai 11 juta jiwa lebih, hal ini terutama karena relatif tingginya jumlah penduduk yang beraktifitas di wilayah DKI Jakarta tetapi bukan merupakan penduduk terdaftar dan bermukim di wilayah ini (commuters).

Pesatnya laju pembangunan fisik dan semakin bertambah padatnya penduduk Kota Jakarta memberikan dampak pada semakin berkurangnya daya dukung lahan dan lingkungan di wilayah tersebut. Dalam proses transisi dari kota metropolitan menjadi megapolitan, Pemda DKI Jakarta terus menghadapi tantangan berat untuk dapat mewujudkan cita-cita atau harapan bersama menjadi sebuah kota yang layak untuk dihuni (livable city) dalam rangka mendukung produktifitas 
Tabel 1. Jumlah Kepadatan Penduduk DKI Jakarta per Wilayah Kotamadya ; bulan Januari 2009

\begin{tabular}{|l|l|l|l|l|l|l|l|}
\hline \multirow{2}{*}{ Wilayah } & \multicolumn{3}{|c|}{ WNI } & \multicolumn{3}{c|}{ WNA } & Total \\
\cline { 2 - 8 } & LK & PR & Jumlah & LK & PR & Jumlah & \\
\hline Jakarta Pusat & & & & & & & \\
\hline Jakarta Utara & & & & & & & \\
\hline Jakarta Barat & & & & & & & \\
\hline Jakarta Selatan & & & & & & & \\
\hline Jakarta Timur & & & & & & & \\
\hline Kep. Seribu & & & & & & & \\
\hline TOTAL & & & & & & & \\
\hline
\end{tabular}

\begin{tabular}{|l|r|r|r|r|r|r|r|}
\hline \multirow{2}{*}{ Wilayah } & \multicolumn{5}{|c|}{ WNI } & \multicolumn{3}{c|}{ WNA } & Total \\
\cline { 2 - 9 } & LK & PR & Jumlah & LK & PR & Jumlah \\
\hline Jakarta Pusat & 506.154 & 420.577 & 926.731 & 200 & 141 & 341 & 927.072 \\
\hline Jakarta Utara & 777.257 & 644.621 & 1.421 .878 & 277 & 236 & 513 & 1.422 .391 \\
\hline Jakarta Barat & 869.470 & 764.739 & 1.634 .209 & 334 & 302 & 636 & 1.634 .845 \\
\hline Jakarta Selatan & 1.062 .617 & 829.883 & 1.892 .500 & 396 & 256 & 652 & 1.893 .152 \\
\hline Jakarta Timur & 1.419 .794 & 1.192 .244 & 2.612 .038 & 113 & 105 & 218 & 2.612 .256 \\
\hline Kep. Seribu & 11.215 & 10.237 & 21.452 & 0 & 0 & 0 & 21.452 \\
\hline TOTAL & 4.646 .507 & 3.862 .301 & 8.508 .808 & 1.320 & 1.040 & 2.360 & 8.511 .168 \\
\hline
\end{tabular}

Sumber : Suku Dinas Kependudukan dan Catatan Sipil Kotamadya, Propinsi DKI Jakarta (2009)

warganya mencapai tingkat kesejahteraan ekonomi dan sosial yang maksimal. Sementara itu, dalam saat bersamaan perubahan tataguna lahan dan perubahan iklim (climate change) akibat dampak dari pemanasan global (global warming) telah secara signifikan menimbulkan akumulasi masalah lingkungan bagi Kota Jakarta.

Berdasarkan penelitian para ahli International Institute for Environment and Development Britinia bekerjasama dengan City University of New York dan Colombia University, Jakarta dikategorikan sebagai salah satu kota di dunia yang bakal merasakan dampak pemanasan global yaitu akan tenggelam paling lambat hingga akhir abad ini. Berdasarkan hasil pemantauan kualitas lingkungan yang dilakukan sejumlah lembaga lingkungan, dilaporkan bahwa kualitas lingkungan di wilayah Jakarta makin menurun dan kian hari semakin mengkhawatirkan.

Permasalahan lingkungan yang paling krusial di wilayah DKI Jakarta adalah permasalahan yang terkait dengan aspek sumberdaya air, seperti permasalahan banjir, krisis ketersediaan air baku, pencemaran air dan penurunan muka air tanah. Kejadian banjir di wilayah Jakarta seolah menjadi topik berita setiap hari setiap kali musim hujan tiba. Sebaliknya pada saat musim kemarau tiba, giliran permasalahan kelangkaan air baku yang harus dihadapi oleh penduduk Kota Jakarta. Kondisi demikian menyebabkan banyak penduduk Kota Jakarta mengeksploitasi air tanah secara tak terkendali, yang secara tidak sadar justru menimbulkan masalah lain yaitu penurunan muka air tanah yang diikuti dengan penurunan permukaan tanah dan terjadinya instrusi air laut. Buruknya kualitas air akibat tingginya tingkat pencemaran air oleh limbah industri maupun domestik semakin memperparah krisis air di wilayah DKI Jakarta.

Permasalahan sumberdaya air di wilayah DKI Jakarta yang sudah sedemikian kompleks tersebut perlu mendapat perhatian khusus tidak hanya oleh Pemerintah Daerah Propinsi DKI Jakarta saja, tetapi juga oleh Pemerintah Pusat, karena bagaimanapun Kota Jakarta merupakan citra bangsa Indonesia di mata dunia internasional. Penanganan semua permasalahan tersebut tidak dapat dilakukan secara parsial, tetapi harus dilakukan secara menyeluruh dan terpadu.

Tabel 2 berikut menyajikan perhitungan neraca air dan hasil proyeksi kebutuhan air baku PAM DKI Jakarta sampai tahun 2025 yang disusun oleh Badan Regulator Pelayanan Air Minum Jakarta (2006). 
Tabel 2. Neraca Air dan Proyeksi Kebutuhan Air Baku PAM DKI sampai tahun 2025

\begin{tabular}{|c|c|c|c|c|c|c|c|}
\hline \multirow{2}{*}{ No. } & \multirow{2}{*}{ Design Parameter } & \multirow{2}{*}{ Satuan } & \multicolumn{4}{|c|}{ Tahun } & \multirow{2}{*}{ Catatan } \\
\hline & & & 2010 & 2015 & 2020 & 2025 & \\
\hline 1. & Total Penduduk (1000) & Capita & 11,437 & 12,333 & 13,272 & 14,258 & Termasuk Komuter \\
\hline 2. & Target Cakupan Layanan & $\%$ & 70 & 80 & 90 & 100 & \\
\hline 3. & Target Pend Terlayani (1.000) & Capita & 8,006 & 9,866 & 11,945 & 14,258 & \\
\hline 4. & Tingkat Penggunaan Air Tanah & $\%$ & 30 & 20 & 10 & 0 & \\
\hline 5. & Tingkat Konsumsi Jiwa & $1 / \mathrm{c} / \mathrm{h}$ & 160 & 175 & 225 & 250 & \\
\hline 6. & Total Kebutuhan Air Bersih & $1 / \mathrm{dt}$ & 16,217 & 22,839 & 31,108 & 41,256 & \\
\hline 7. & Non Revenye Water (NRW) & $\%$ & 40 & 35 & 30 & 25 & \\
\hline 8. & Total Kebutuhan Air Baku & $1 / \mathrm{dt}$ & 27,028 & 35,138 & 44,440 & 55,008 & \\
\hline 9. & Air Baku Tersedia Saat ini & $1 / \mathrm{dt}$ & 16.000 & 16.000 & 16.000 & 16.000 & \\
\hline 10. & DEFISIT AIR BAKU & $1 / \mathrm{dt}$ & 11,028 & 19,138 & 28,440 & 39,008 & \\
\hline 11. & Potensi Reklamasi L. Cair & $1 / \mathrm{s}$ & 9,730 & 13,703 & 18,665 & 24,754 & $60 \%$ Konsumsi $\mathrm{AB}$ \\
\hline 12. & Potensi Cadangan Air Hujan & $1 / \mathrm{s}$ & 47,500 & 47,500 & 47,500 & 47,500 & Rata-2 Tahunan \\
\hline
\end{tabular}

Sumber : Hasil Analisa BRPAM Jakarta (2006)

Dari tabel di atas secara makro terlihat bahwa defisitair baku di wilayah DKI Jakarta sebesar 11,028 I/dt pada tahun 2010 akan terus membengkak menjadi 39,008 I/dt pada akhir tahun 2025. Hasil proyeksi ini harus segera disikapi agar krisis air yang sekarang sudah dirasakan oleh penduduk yang tinggal di wilayah DKI Jakarta tidak semakin bertambah parah dampaknya. Berdasarkan itu, maka tindakan konservasi air merupakan suatu kegiatan yang mutlak harus dilakukan sebagai upaya penyelamatan sumberdaya air di wilayah DKI Jakarta.

Tulisan ini merupakan hasil review dari beberapa pustaka yang terkait dengan topik dalam tulisan ini yaitu dengan fokus pembahasan mengenai bentuk upaya konservasi air yang bersifat konvensional menggunakan teknik pemanenan air hujan (rain water harvesting). Berdasarkan hasil review tersebut, selanjutnya dibahas secara detail mengenai berbagai permasalahan sumberdaya air di wilayah DKI Jakarta yang sangat kompleks. Pembahasan yang dituliskan merupakan tinjauan penulis dari sudut pandang suatu konsep pengelolaan sumberdaya air secara terpadu untuk suatu wilayah perkotaan (Integrated Urban Water Resources Management ; IUWRM).

\section{MASALAH PENGELOLAAN SUMBER AIR DI WILAYAH DKI JAKARTA}

Ali (2009) menyebutkan beberapa hal krusial yang terkait dengan masalah pengelolaan sumberdaya air di DKI Jakarta diantaranya adalah sebagai berikut :

\subsection{Bencana Banjir dan Upaya Pengendaliannya}

Pengelolaan sumberdaya air yang selalu melahirkan kekhawatiran masyarakat dan pemerintah setiap musim hujan datang adalah ancaman banjir. Perubahan tataguna lahan, semakin terbatasnya kemampuan saluran drainase kota dalam menerima limpasan air hujan ditambah dengan prilaku masyarakat yang menjadikan saluran air atau sungai sebagai tempat pembuangan sampah serta akibat dampak dari perubahan iklim global semakin memperberat upaya pengendalian banjir di wilayah ibu kota ini.

Sebagian besar wilayah di DKI Jakarta tidak luput dari ancaman bahaya banjir yang frekuensi dan intensitasnya semakin tinggi. Setiap musim hujan pada beberapa daerah yang merupakan pusat aktifitas bisnis dan pemerintahan selalu terjadi genangan air akibat merosotnya kapasitas saluran drainase yang ada di tengah-tengah perubahan tata guna lahan yang memperbesar air limpasan (run off).

Berdasarkan kondisi topografinya, hampir $50 \%$ dari wilayah Ibu Kota Jakarta berada pada dataran banjir dari 13 sungai yang melewati Kota Jakarta. Diantara ke-13 sungai tersebut, Sungai Ciliwung merupakan sungai yang paling memberikan kontribusi terbesar bagi kejadian banjir yang menggenangi wilayah Kota Jakarta dan luapan Sungai Ciliwung sangat fatal karena langsung menggenangi daerah pusat kota Jakarta bahkan sampai ke Istana Negara. 
Ancaman banjir merupakan pekerjaan rumah yang tidak mudah bagi Pemda DKI Jakarta. Bencana banjir besar pada awal tahun 2002 dan 2007 di wilayah Jabodetabek telah menyebabkan total kerugian mencapai Rp. 18,7 triliun dengan korban jiwa mencapai 159 jiwa. Bisa dibayangkan kerugian yang diperoleh masyarakat setiap tahunnya akibat bencana banjir apabila tidak segera dilakukan upaya penanganan terpadu dan menyeluruh.

\subsection{Kelangkaan Air Baku dan Cakupan Pelayanan}

Penyediaan air bersih yang memenuhi persyaratan standar pelayanan merupakan tantangan serius yang dihadapi oleh Pemda DKI Jakarta dewasa ini. Sistem pelayanan air bersih dengan sistem perpipaan di DKI Jakarta sejak tahun 1998 dipercayakan oleh Perusahan Air Minum (PAM) DKI Jaya kepada dua mitra swasta asing, yaitu :

1. PT. Garuda Dipta Semesta (Salim Group \& Lyonnaise Des Eaux), sekarang berubah nama menjadi PT. PAM Lyonnaise Jaya atau PALYJA (untuk wilayah barat Sungai Ciliwung); dan

2. PT. Kekarpola Thames Airindo (PT. Kekarpola Airindo dan Thames Water Overseas, Ltd), sekarang berubah nama menjadi Thames PAM JAYA atau TPJ (untuk wilayah timur Sungai Ciliwung)

Sampai saat ini keduanya baru mampu melayani $44 \%$ dari total jumlah penduduk Jakarta. Kondisi pelayanan yang terkait dengan kualitas, kuantitas, kontinuitas dan tekanan air masih mendominasi keluhan atau komplain dari masyarakat pelanggan Palyja dan TPJ.

Dua faktor yang menyebabkan keterbatasan tersebut yang satu sama lain semakin memperburuk kinerja pelayanan air bersih di Jakarta adalah semakin tingginya tingkat inefisiensi (kebocoran) yang saat ini mencapai $50 \%$ lebih dalam bentuk kehilangan air (Uncounted for Water atau UFW) dan akibat semakin terbatasnya suplai air baku yang berasal dari sumber utama Waduk Serbaguna Jatiluhur.

Berdasarkan perhitungan dari Badan Regulator Pelayanan Air Minum (BR-PAM) DKI Jakarta, defisit air baku terhadap total kebutuhan air bersih dalam 5 tahun terakhir sudah dalam keadaan yang sangat mengkhawatirkan. Pada tahun 2005, total air bersih yang harus diproduksi dari seluruh instalasi produksi yang masih beroperasi ( 7 instalasi) adalah sebesar $25,8 \mathrm{~m}^{3} / \mathrm{dt}$ sementara suplai air baku yang tersedia rata-rata $14,6 \mathrm{~m}^{3} / \mathrm{dt}$. Defisit air baku tahun 2005 sebesar $11.2 \mathrm{~m}^{3} / \mathrm{dt}$ akan terus meningkat disebabkan adanya kecenderungan turunnya kemampuan Waduk Jatiluhur dalam mengalirkan air baku melalui Saluran Tarum Barat yang berjarak $\pm 70 \mathrm{~km}$ dari Jakarta akibat semakin tingginya kebutuhan air untuk keperluan pertanian, perkotaan dan industri di sepanjang saluran Tarum Barat/Kali Malang serta akibat perubahan iklim dan tataguna lahan pada wilayah tangkapan air (catchment area) Waduk Jatiluhur, Cirata dan Saguling di bagian hulu.

Kondisi dan keberlanjutan suplai air bersih dari luar wilayah Jakarta dalam perjalanan waktu terus mengalami perubahan baik secara teknis akibat penurunan debit (mata air Ciburial - Bogor sebagai contoh) maupun akibat perubahan orientasi politik dan ekonomi dalam era otonomi daerah dewasa ini, seperti yang terjadi dengan kasus pengurangan suplai air curah dari PDAM Kabupaten Tangerang pada awal tahun 2007.

Kondisi ini haruslah menjadi pertimbangan dalam rencana pengembangan dan peningkatan sistem pelayanan air bersih di masa yang akan datang. Karena daerah-daerah seperti Bogor dan Tangerang akan terus berkembang dan akan terus lebih membutuhkan air bersih untuk pemenuhan kebutuhan di wilayah mereka. Karena dalam menghadapi kecenderungan perubahan ekologi akibat aktifitas manusia dan gangguan siklus hidrologi akibat adanya perubahan iklim global yang mengancam ketersediaan air, tentunya sistem penyediaan air bersih yang saat ini ada dan belum sepenuhnya dimanfaatkan untuk melayani kebutuhan di daerah-daerah tersebut di waktu yang akan datang tentunya akan diprioritaskan untuk memenuhi kebutuhan di daerah tersebut.

\subsection{Penanganan Limbah Cair}

Sebagai kota metropolitan, Jakarta saat ini belum memiliki Sistem Penanganan Air Limbah (wastewater treatment system) perkotaan yang memenuhi standar kesehatan lingkungan. Fasilitas penanganan limbah cair yang merupakan proyek percontohan bantuan Pemerintah Jepang pada dekade 80 dan 90-an untuk melayani wilayah Setiabudi dan Tebet dengan memanfaatkan Waduk Pengendali Banjir Setiabudi hingga saat ini baru mampu melayani $2,8 \%$ dari total populasi dan wilayah yang ada. Dari segi pilihan teknologi sistem pengolahan limbah cair tersebut masih sangat sederhana atau sudah ketinggalan zaman untuk sebuah kota metropolitan sebesar Jakarta.

Akibat rendahnya komitmen Pemda DKI maupun pemerintah pusat terhadap sektor air limbah, maka sampai saat ini sebagian besar limbah cair domestik yang dihasilkan masih terus dibuang ke saluran terbuka (sungai/kali/selokan) sehingga menyebabkan badan air penerima tersebut terus mengalami kontaminasi. Kondisi septic tank yang 
digunakan pada daerah yang sudah semakin padat juga menyebabkan kontaminasi air tanah dangkal/sumur yang semakin mengkhawatirkan. Tidak mengherankan hingga saat ini, kasus wabah penyakit yang disebabkan oleh penggunaan sumber air yang terkontaminasi masih terhitung tinggi di beberapa daerah di wilayah Ibukota Jakarta (PBHD-DKI, 2007).

\subsection{Pengelolaan Kualitas Permukaan}

Kualitas 13 sungai yang melewati wilayah DKI Jakarta dari waktu ke waktu terus mengalami pencemaran oleh buangan rumah tangga dan industri. Program perbaikan kualitas sungai melalui Program Kali Bersih (Prokasih) pada awal tahun 90-an yang kemudian terhenti karena krisis moneter dan ekonomi melanda Indonesia ternyata tidak mampu memenuhi target yang ditetapkan. Akibat perubahan kualitas air yang sangat signifikan tersebut, bisa dipastikan bahwa hampir tidak ada sungai-sungai dalam kota yang bisa dijadikan sebagai sumber air baku bagi PAM DKI. Beberapa instalasi pengolahan air bersih skala kecil (mini water treatment plant) yang pada awalnya menggunakan beberapa sungai yang ada di dalam kota sebagai sumber air bakunya sudah tidak dapat difungsikan lagi akibat buruknya kualitas airnya serta semakin berkurangnya debit air, terutama selama musim kemarau.

Keinginan Pemda DKI Jakarta untuk mengembangkan wisata dan transportasi air (Water Way) tentunya akan terkendala akibat jeleknya kondisi kualitas sungai-sungai yang ada termasuk bantarannya. Disamping dibutuhkan komitmen yang tinggi dari pemerintah dan masyarakat untuk tidak lagi menjadikan sungai sebagai tempat pembuangan limbah (cair dan padat) tentunya diperlukan biaya yang sangat besar untuk bisa merestorasi untuk memulihkan kembali kondisi dan kualitas sungai-sungai tersebut.

\subsection{Pengendalian Eksploitasi Pencemaran Air Tanah}

dan

Karena rendahnya cakupan layanan air bersih perpipaan yang tersedia disamping terkait dengan masalah tarif air minum, penggunaan air tanah dangkal, sedang dan dalam telah merupakan suatu fenomena umumyang tidak dapatdihindarkan. Karena tidak adanya jaminan dan kepastian pelayanan air bersih yang diberikan oleh PAMJaya melalui 2 mitra swastanya (terutama dalam segi kualitas, kuantitas dan kontinuitas), beberapa institusi komersial (industri, perkantoran, hotel dan apartemen) melakukan pengambilan (ekstraksi) air tanah dalam dengan menggunakan sistem pemompaan dalam kapasitas yang relatif besar yang dapat berakibat terganggunya ketersediaan dan keseimbangan air tanah untuk mendukung fungsi ekosistem yang ada.

Sebagaimana diketahui, penurunan muka air tanah merupakan salah satu faktor yang menyebabkan penurunan muka tanah di wilayah Jakarta. Akibat tingkat ekstraksi air tanah yang berlebihan tersebut, yang melebihi kemampuan pengisian kembali (recharge) secara alami, masalah ekologi yang sedang berlangsung adalah terjadinya kencenderungan penurunan muka air tanah secara drastis yang berakibat pada penurunan elevasi permukaan tanah pada beberapa daerah di Jakarta dan pergerakan signifikan intrusi air laut dari utara ke selatan. Penurunan permukaan tanah ini dapat menyebabkan potensi volume dan permukaan genangan air pada musim hujan (banjir) bertambah secara signifikan, sedangkan pada saat musim kemarau, karena perubahan tekanan hidrolis pada sistem geohidrologis air tanah di wilayah dekat pantai dan akibat tingkat ektraksi air tanah sedang dan dalam yang sangat tinggi, intrusi air laut bergerak dengan sangat cepat dari utara ke arah selatan bahkan sudah hampir mencapai wilayah Jakarta Selatan.

Sementara itu, khususnya pada air tanah dangkal karena belum tersedianya sistem penangan limbah cair yang memenuhi persyaratan sanitasi, sebagian besar air tanah di wilayah DKI Jakarta tercemar oleh limbah cair rumah tangga yang terlihat dari indikasi kandungan Fecal Coli Form yang sangat tinggi. Hasil pemantauan yang dilakukan oleh BPLHD DKI Jakarta pada tahun 2004 dan 2005 menunjukkan bahwa 67\% dari sumur yang dipantau mengandung bakteri coliform dan $58 \%$ diantaranya mengandung fecal coli melebihi baku mutu.

\section{ALTERNATIF SOLUSI MASALAH SUMBER DAYA AIR MELALUI UPAYA KONSERVASI AIR DENGAN TEKNIK PEMANENAN AIR HUJAN (RAIN WATER HARVESTING)}

Maryono dan Santoso (2006) menyebutkan bahwa di dunia internasional saat ini upaya memanen hujan telah menjadi bagian penting dalam agenda global environmental water resources management dalam rangka penanggulangan ketimpangan air pada musim hujan dan kering (lack of water), kekurangan pasokan air bersih penduduk dunia, serta penanggulangan banjir dan kekeringan. Teknik pemanenan air hujan atau disebut juga dengan istilah rain water harvesting didefinisikan sebagai suatu cara pengumpulan atau 
penampungan air hujan atau aliran permukaan pada saat curah hujan tinggi untuk selanjutnya digunakan pada waktu air hujan rendah.

Dilihat dari ruang lingkup implementasinya, teknik ini dapat digolongkan dalam 2 (dua) kategori, yaitu :

1. Teknik pemanenan air hujan dengan atap bangunan (roof top rain water harvesting), dan

2. Teknik pemanenan air hujan (dan aliran permukaan) dengan bangunan reservoir, seperti dam parit, embung, kolam, situ, waduk, dan sebagainya.

Perbedaan dari kedua kategori di atas adalah bahwa untuk kategori yang pertama, ruang lingkup implementasinya adalah pada skala individu bangunan rumah dalam suatu wilayah permukiman ataupun perkotaan ; sementara untuk kategori yang kedua skalanya lebih luas lagi, biasanya untuk suatu lahan pertanian dalam suatu wilayah DAS ataupun subDAS. Untuk selanjutnya, tulisan ini hanya akan membahas kategori yang pertama saja berkaitan dengan ruang lingkupnya yang sesuai untuk wilayah permukiman atau perkotaan.

Sesuai dengan namanya, teknik pemanenan

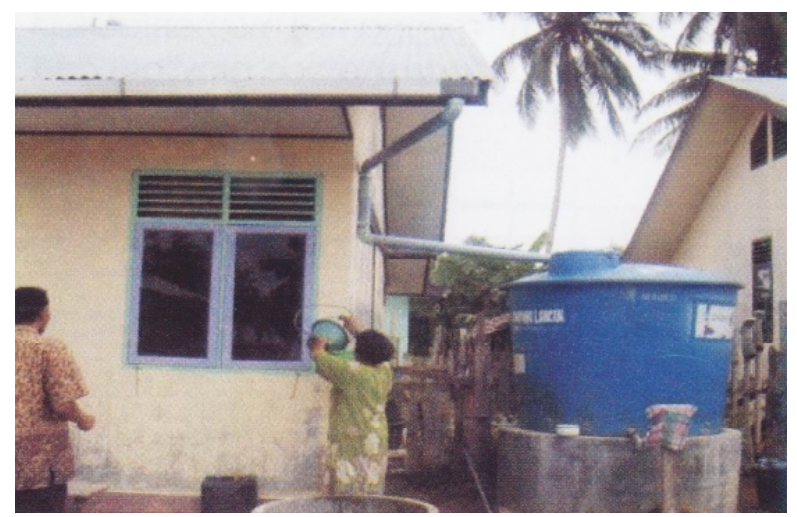

Gambar 1. Bangunan tangki penampung air hujan di Kabupaten Pidie, NAD

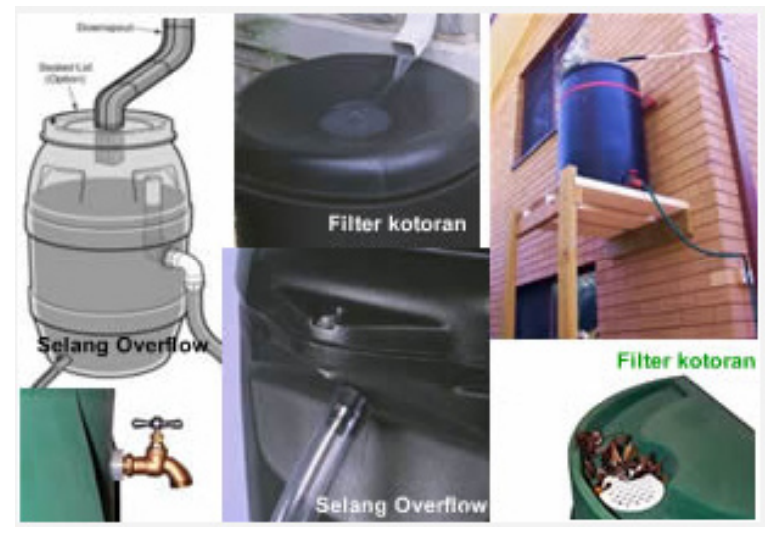

Gambar 3. Tempat penampung air hujan dengan tong air hujan dengan atap bangunan (roof top rain water harvesting) pada prinsipnya dilakukan dengan memanfaatkan atap bangunan (rumah, gedung perkantoran, atau industri) sebagai daerah tangkapan airnya (catchment area) dimana air hujan yang jatuh di atas atap kemudian disalurkan melalui talang untuk selanjutnya dikumpulkan dan ditampung ke dalam tangki (Gambar 1) atau bak penampung air hujan (Gambar 2). Selain berbentuk tangki atau bak, tempat penampungan air hujan juga dapat berupa tong air biasa (Gambar 3) ataupun dalam suatu kolam/taman di dalam rumah (Gambar 4). Teknik pemanenan air hujan yang memanfaatkan atap bangunan ini umumnya dilakukan di daerah permukiman / perkotaan.

Al Amin et al (2008) menyebutkan bahwa konstruksi untuk bangunan pemanen air hujan dapat dibuat dengan cepat karena cukup sederhana dan mudah dalam pembuatannya. Komponenkomponen utama konstruksi tampungan air hujan seperti yang digambarkan dalam Gambar 5, terdiri dari : atap rumah, saluran pengumpul (collector channel), filter untuk menyaring daun-daun atau kotoran lainnya yang terangkut oleh air, dan bak penampung air hujan.

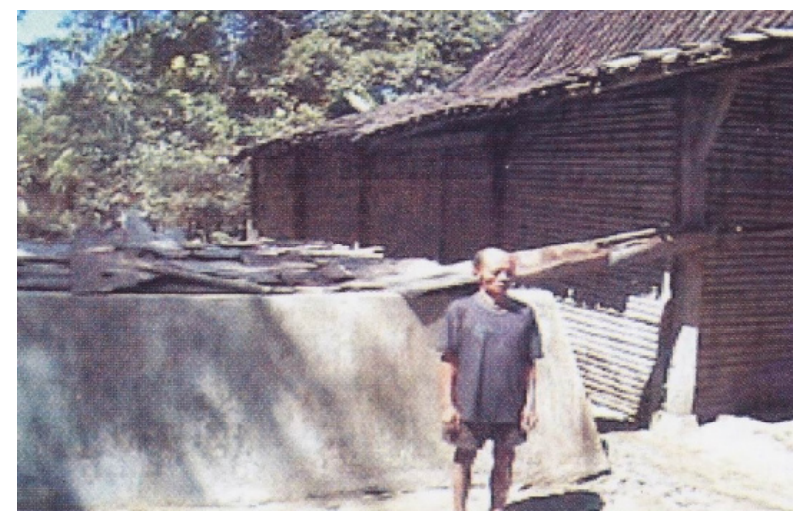

Gambar 2. Bangunan bak penampung air hujan di Kabupaten Gunung Kidul, DIY.

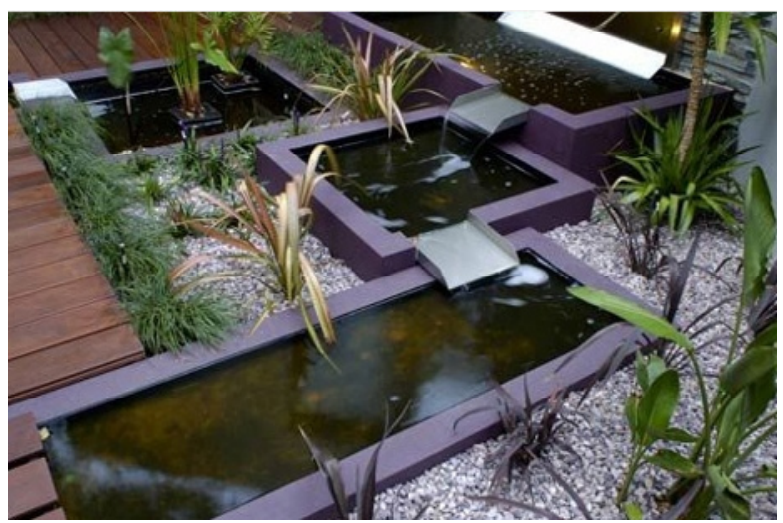

Gambar 4. Tempat penampung air hujan berbentuk taman/kolam di dalam rumah 


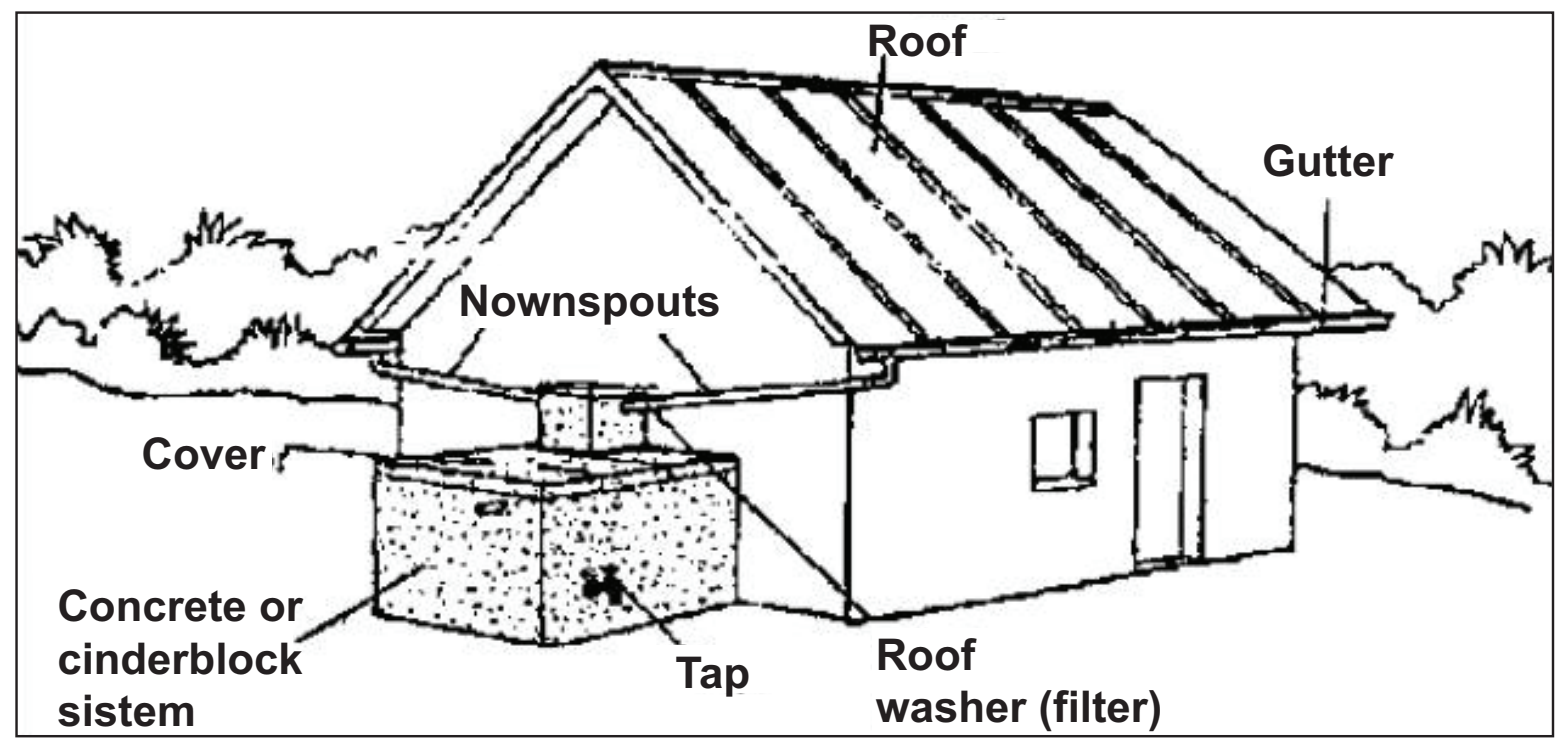

Gambar 5. Skema teknik panen hujan dengan atap rumah

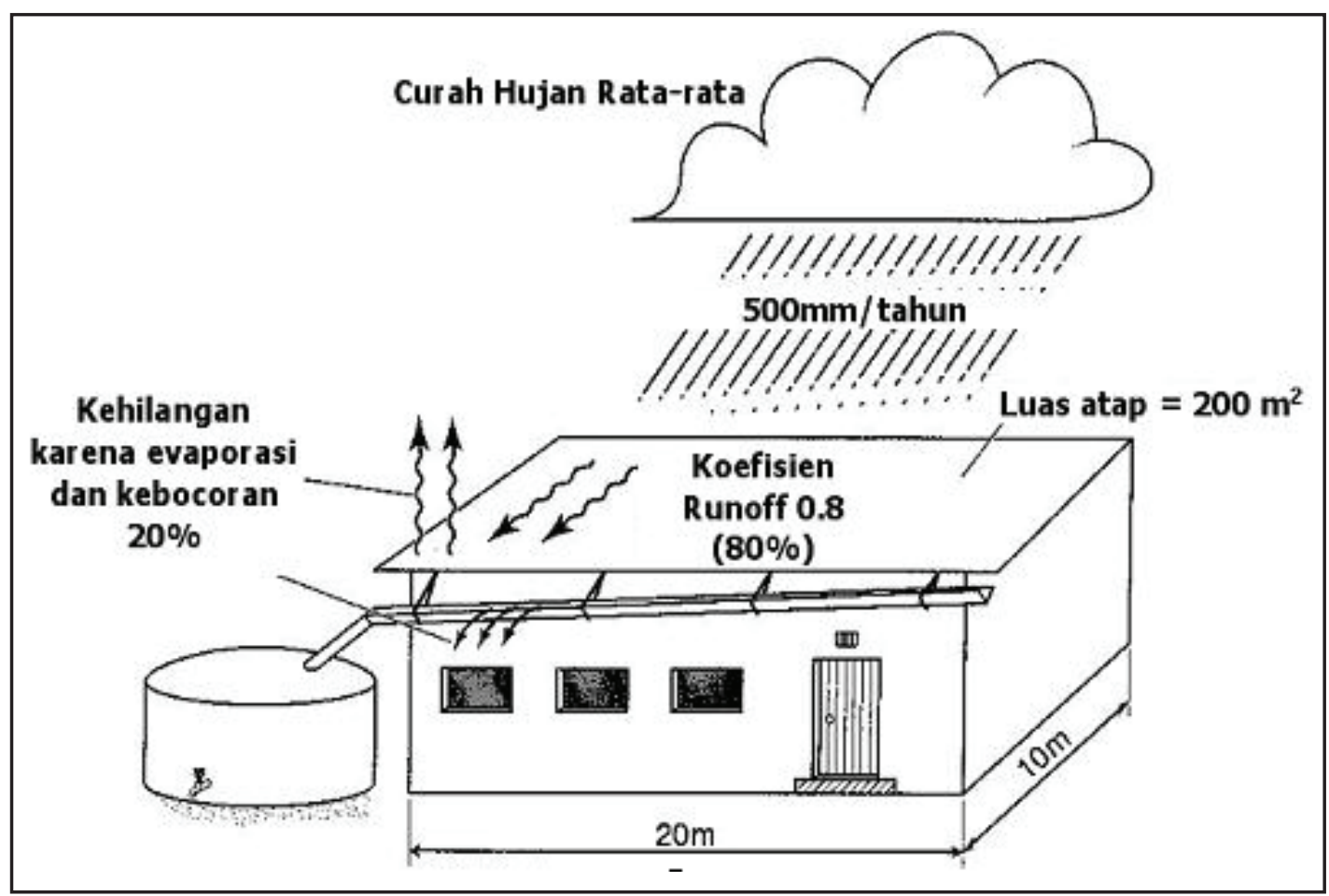

Gambar 6. Ilustrasi bangunan penampung air hujan dari atap rumah

Heryani (2009) dalam tulisannya yang berjudul Teknik Panen Hujan : Salah Satu Alternatif Untuk Memenuhi Kebutuhan Air Domestik menjelaskan bahwa potensi jumlah air yang dapat dipanen (the water harvesting potential) dari suatu bangunan atap dapat diketahui melalui perhitungan s ecara sederhana, sebagai berikut:

Jumlah air yang dapat dipanen $=$ Luas area $X$ curah hujan $X$ koefisien runoff

Sebagai ilustrasi (seperti disajikan pada Gambar 6), untuk suatu areal tangkapan hujan dengan luas $200 \mathrm{~m}^{2}$, curah hujan tahunan $500 \mathrm{~mm}$, maka jumlah air yang dapat dipanen ditetapkan sebagai berikut :

v Dengan luas area $=200 \mathrm{~m}^{2}$ dan jumlah curah hujan tahunan $=500 \mathrm{~mm}$, maka volume air hujan yang jatuh di area tersebut: $=20.000 \mathrm{dm}^{2} \times 5 \mathrm{dm}=100.000$ liter

v Dengan asumsi hanya $80 \%$ dari total hujan yang dapat dipanen $(20 \%$ hilang karena evaporasi atau kebocoran), maka volume yang dapat dipanen :

$$
=100.000 \times 0.8=80.000 \text { liter/tahun. }
$$




\section{PEMBAHASAN}

Sebelum membahas lebih jauh mengenai solusi untuk permasalahan sumberdaya air di wilayah DKI Jakarta, perlu diketahui terlebih dahulu kondisi curah hujan untuk wilayah DKI Jakarta dan sekitarnya. Berdasarkan data curah hujan historis sejak tahun 1989 - 2008 dari beberapa lokasi stasiun penakar hujan yang berada di sekitar DAS Ciliwung (Gambar 7 dan Tabel 3), wilayah DKI Jakarta (DAS Ciliwung Hilir) mempunyai nilai curah hujan tahunan sebesar $1.929 \mathrm{~mm} /$ tahun. Sementara itu, DAS Ciliwung Hulu yang juga memberikan kontribusi terhadap pasokan air di wilayah DKI Jakarta mempunyai curah hujan tahunan $3.502 \mathrm{~mm} /$ tahun.

Dengan kondisi curah hujan seperti yang ditunjukkan dalam Tabel 3, penduduk yang tinggal di Kota Jakarta semestinya tidak perlu mengalami krisis ketersediaan air bersih. Inflow air untuk wilayah Jakarta dari air hujan sebenarnya masih tergolong tinggi, namun daya dukung lahan yang sudah menurun dan kondisi lingkungan (DAS) yang sudah rusak menyebabkan wilayah ini mengalami krisis air baku ditinjau dari segi kuantitasnya.

Dari hasil studi pustaka, teknik konservasi air dengan metode Roof Top Rain Water Harvesting dinilai mempunyai potensi yang cukup besar untuk mengatasi permasalahan krisis ketersediaan air baku di Jakarta jika saja masyarakatnya mau untuk mulai melakukan upaya konservasi air dengan memanen air hujan di lingkungan rumah masing-masing. Meski sudah cukup lama dikenal di Indonesia, namun pada kenyataannya teknik konservasi ini belum banyak diimplementasikan secara serius. Memang sudah banyak orang yang menyalurkan air hujan dari atap rumahnya dengan sistem paralon, namun sayangnya air itu langsung diarahkan untuk dibuang ke selokan. Padahal jika air hujan dari atap tersebut ditampung dan dikumpulkan untuk dimanfaatkan, teknik ini dapat mengurangi krisis air yang umumnya terjadi di kota-kota besar yang padat penduduknya, seperti halnya Kota Jakarta.

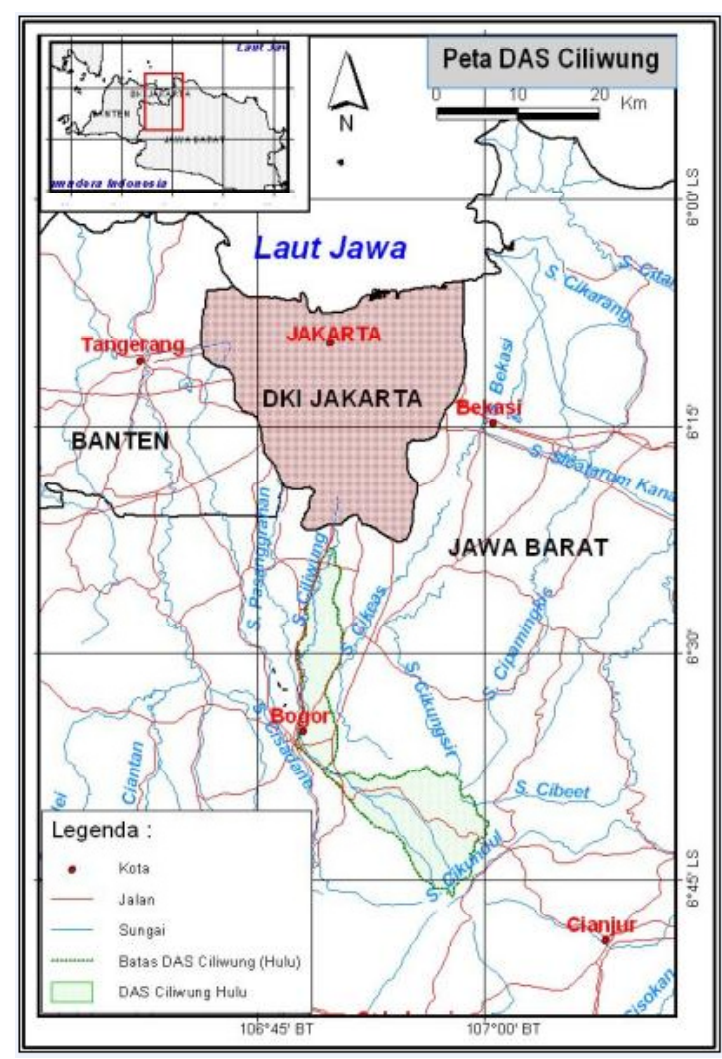

Gambar 7. Peta DAS Ciliwung

Tabel 3. Curah Hujan Historis (1989-2008) DAS Ciliwung

\begin{tabular}{|c|c|c|c|c|c|c|c|c|c|c|c|c|c|}
\hline Stasiun & JAN & FEB & MAR & APR & MEI & JUN & JUL & AGS & SEP & OKT & NOP & DES & ANNUAL \\
\hline \multicolumn{14}{|l|}{ Ciliwung Hulu } \\
\hline Gunung Mas & 567 & 659 & 436 & 346 & 238 & 180 & 102 & 82 & 152 & 252 & 387 & 379 & 3,778 \\
\hline Citeko & 454 & 536 & 334 & 272 & 164 & 99 & 78 & 61 & 102 & 283 & 295 & 303 & 2,981 \\
\hline Pasir Muncang & 467 & 399 & 311 & 227 & 153 & 136 & 94 & 77 & 109 & 207 & 274 & 235 & 2,688 \\
\hline Gadog & 462 & 391 & 350 & 303 & 247 & 187 & 182 & 140 & 195 & 365 & 327 & 235 & 3,382 \\
\hline Katulampa & 472 & 439 & 421 & 366 & 326 & 218 & 212 & 187 & 358 & 391 & 454 & 291 & 4,035 \\
\hline Kebun Raya & 359 & 370 & 397 & 436 & 296 & 237 & 221 & 137 & 170 & 412 & 389 & 275 & 3,699 \\
\hline Empang & 402 & 409 & 350 & 418 & 433 & 268 & 187 & 180 & 238 & 373 & 416 & 279 & 3,951 \\
\hline Rerata Hulu & 455 & 457 & 371 & 338 & 265 & 189 & 154 & 124 & 175 & 326 & 363 & 285 & 3,502 \\
\hline \multicolumn{13}{|l|}{ Ciliwung Hilir } & ANNUAL \\
\hline BMG Jakarta & 342 & 336 & 142 & 142 & 110 & 52 & 98 & 44 & 26 & 135 & 132 & 166 & 1,726 \\
\hline Cwngkareng & 320 & 309 & 127 & 99 & 93 & 52 & 71 & 39 & 42 & 89 & 113 & 134 & 1,487 \\
\hline Ciledug & 345 & 299 & 245 & 250 & 203 & 65 & 93 & 59 & 116 & 163 & 178 & 210 & 2,227 \\
\hline Depok & 418 & 356 & 246 & 382 & 178 & 143 & 124 & 74 & 92 & 384 & 326 & 241 & 2,914 \\
\hline Halim & 312 & 287 & 225 & 219 & 138 & 75 & 85 & 33 & 49 & 183 & 178 & 158 & 1,944 \\
\hline Pakubuwono & 320 & 262 & 213 & 189 & 157 & 127 & 86 & 36 & 49 & 104 & 166 & 189 & 1,897 \\
\hline Rasela & 380 & 272 & 156 & 196 & 114 & 119 & 97 & 41 & 50 & 102 & 132 & 158 & 1,817 \\
\hline Rawamangun & 363 & 321 & 156 & 163 & 111 & 116 & 66 & 25 & 65 & 153 & 124 & 116 & 1,778 \\
\hline Tanjung Priuk & 366 & 382 & 131 & 87 & 65 & 46 & 62 & 28 & 47 & 86 & 87 & 188 & 1,574 \\
\hline Rerata Hilir & 352 & 314 & 182 & 193 & 130 & 88 & 87 & 42 & 60 & 150 & 160 & 173 & 1,929 \\
\hline
\end{tabular}

Sumber : UPT Hujan Buatan - BPPT 
Berikut ini ilustrasi untuk menunjukkan bagaimana teknik Roof Top Rain Water Harvesting dapat memberikan kontribusi dengan hasil yang cukup signifikan untuk dijadikan sebagai solusi alternatif terhadap permasalahan krisis ketersediaan air baku di Jakarta :

N Misalnya, untuk suatu atap bangunan dengan luas area $100 \mathrm{~m}^{2}\left(=10.000 \mathrm{dm}^{2}\right)$; dan Jumlah curah hujan tahunan untuk wilayah DKI Jakarta berdasarkan data pada Tabel 3 adalah $1.929 \mathrm{~mm} /$ tahun (19,29 dm); maka

v Volume air hujan yang jatuh di satu atap rumah dengan luas atap $100 \mathrm{~m}^{2}$ dalam satu tahun adalah sebanyak :

$=10.000 \mathrm{dm}^{2} \times 19,29 \mathrm{dm}$

= 192.900 liter/tahun

Nengan asumsi hanya $80 \%$ dari total hujan yang dapat dipanen (sesuai ilustrasi yang dicontohkan pada Gambar 2.10 sebelumnya;20\% hilang karena evaporasi atau kebocoran), maka volume air yang dapat dipanen :

$=80 \% \times 192.900$ liter

= 154.320 liter/tahun.

^ Dari volume air tampungan yang dapat dipanen sebanyak 154.320 liter/tahun atau setara dengan 40.763 galon air (1 liter $=0,264$ galon), jika air galonan diasumsikan seharga Rp.1.000,00 galon air saja, maka dari segi pengeluaran satu keluarga sudah terjadi penghematan sebanyak Rp.40.763.000,000/ tahun.

Menurut Ali (Kompas, 10 Mei 2009), standar setiap orang membutuhkan 190 liter air per hari dan dunia usaha membutuhkan 30 persen dari total kebutuhan domestik. Secara total, masyarakat Jakarta membutuhkan air bersih 2,099 miliar liter per hari atau 24.300 liter per detik. Berdasarkan keterangan tersebut maka :

Jika diasumsikan rata-rata dalam satu keluarga terdiri atas 6 orang, maka volume air tampungan mampu untuk mencukupi kebutuhan air satu keluarga selama :

$=154.320 /(190 \times 6)$

= 135 hari (sekitar 4 bulan lebih)

Jika melihat pada kondisi historis curah hujan wilayah DKI Jakarta pada Tabel 3, maka menurut hasil perhitungan di atas volume air yang mampu disimpan dari penampungan air hujan untuk tiap rumah sudah cukup untuk mengatasi kondisi kekurangan air pada saat musim kemarau terjadi di wilayah Jakarta (curah hujan $<100 \mathrm{~mm}$ terjadi selama 4 bulan, yaitu untuk periode Juni sampai dengan September).

Selanjutnya masih berdasarkan keterangan di atas dan mengacu pada data jumlah penduduk DKI Jakarta pada Tabel 1 (terhitung sebanyak 8.511.168 jiwa), maka :

v Jika diasumsikan rata-rata tiap keluarga terdiri atas 6 orang, maka jumlah bangunan rumah di DKI Jakarta diperkirakan kurang lebih ada sejumlah :

$=8.511 .168 / 6$

$=1.418 .528$ bangunan rumah.

v Jika diasumsikan seluruh bangunan rumah di DKI Jakarta sudah melakukan upaya konservasi air dengan teknik Roof Top Rain Water Harvesting, maka total volume air hujan yang tertampung di atap rumah warga di wilayah DKI Jakarta dalam setahun adalah sebanyak :

$=1.418 .528 \times 154.320$ liter/tahun

= 218.907.240.960 liter/tahun

atau setara dengan :

$=218.907 .240 .960$ liter/tahun : 365

= 599.745.866 liter/hari

v Jika hasil perhitungan total volume air hujan yang tertampung di atap rumah warga di seluruh wilayah DKI Jakarta dibandingkan dengan total kebutuhan air bersih penduduk Jakarta yang mengacu pada keterangan sebelumnya sebanyak 2,099 milyar liter / hari, maka rasio persentasenya adalah sebesar :

$=(599.745 .866 / 2.099 .000 .000) \times 100 \%$

$=28.6 \%$

Volume air sebanyak 599.745.866 liter/hari atau sekitar $28,6 \%$ dari total kebutuhan air bersih penduduk Jakarta per harinya, merupakan suatu jumlah yang cukup signifikan untuk dijadikan sebagai tambahan suplai kebutuhan air baku di wilayah DKI Jakarta, disaat suplai utama yang berasal dari Waduk Jatiluhur saat ini sudah tidak mampu lagi mencukupi kebutuhan air baku warga DKI Jakarta.

Semua ilustrasi perhitungan yang telah dibuat di atas baru memperhitungkan kontribusi dari bangunan perumahan saja, belum lagi jika memperhitungkan juga bangunan lainnya seperti industri, perkantoran, perhotelan, pertokoan, dan lain-lain. Dengan manfaat yang telah diilustrasikan di atas, hendaknya kantor-kantor pemerintah dan swasta dapat mulai memanen air hujan untuk mengurangi anggaran air bersih dari PDAM. Untuk komplek-komplek industri juga sangat disarankan untuk menerapkan metode ini. Kebutuhan air untuk industri sebagian besar dapat ditopang dengan memakai air hujan. Tampungan air hujan dapat didistribusikan pada setiap unit bangunan atau dikonsentrasikan dengan membuat tampungan besar atau kolam/danau buatan. Di komplek perhotelan, pertokoan dan komplek-komplek lainnya juga sangat relevan sekali jika menerapkan konsep memanen air hujan ini. Kebutuhan air untuk keperluan-keperluan di luar air minum dapat 
dipasok langsung dari air hujan, sedang kebutuhan air minum, mandi dan cuci dapat dipasok dari air hujan dengan pengolahan (treatment) secukupnya terlebih dahulu. Pemerintah dapat mengimbau bahkan mewajibkan pada komplek-komplek tersebut untuk melakukan upaya memanen air hujan dengan memberi ijin pembangunan atau ijin usaha sekaligus dengan memberikan keringanankeringanan pajak tertentu bagi yang telah melaksanakannya.

Hal yang perlu diperhatikan jika ingin memanfaatkan air yang tertampung dari hasil pemanenan air hujan sebagai substitusi air dari PDAM adalah bahwa selama 5 menit pertama air hujan masih mengandung asam yang berbahaya bagi tubuh, tapi setelah 5 menit, air hujan sudah cocok untuk ditampung ke tempat penampungan. Air hujan yang tertampung mempunyai kualitas yang layak minum setelah air itu diendapkan dan disaring. Sebagai tambahan, pada tempat penampungan air hujan tersebut perlu juga diberikan Abate untuk mencegah berkembangnya bintik-bintik nyamuk.

Teknik pemanenan air hujan selain ramah lingkungan juga dapat menjadi jalan keluar bagi permasalahan sumberdaya air bagi masyarakat yang tinggal di wilayah perkotaan, khususnya di DKI Jakarta. Tidak saja dalam hal menambah cadangan suplai ketersediaan air baku seperti yang telah diilustrasikan di atas, tetapi juga dalam hal lainnya seperti menambah suplai air tanah, mengurangi resiko semakin turunnya permukaan tanah dan terjadinya banjir.

Dengan menampung dan menyimpan air hujan, beban PDAM juga bisa berkurang dan sebagai multiplier effect dari itu adalah berkurangnya intensitas pengambilan (ekstraksi) air tanah dalam oleh rumah tangga atau perkantoran yang terbukti telah mengakibatkan penurunan permukaan tanah di wilayah DKI Jakarta.

Dalam kaitannya dengan pencegahan banjir, teknik pemanenan air hujan juga dapat memiliki peran yang cukup signifikan terutama dalam hal mengurangi potensi air permukaan yang menjadi surface runoff. Hal yang perlu dipahami adalah bahwa kejadian banjir dapat terjadi terutama karena air hujan lebih banyak menjadi air permukaan yang mengalir di selokan dan sungai daripada yang meresap ke dalam tanah. Untuk kasus di wilayah DKI Jakarta, air hujan yang meresap ke dalam tanah sangat sedikit karena daerah tangkapan air (di daerah hulu) telah terganggu dan rusak. Dengan ditampungnya sebagian air hujan pada sejumlah atap rumah warga, maka berarti ada sebagian air hujan yang tertahan dan tidak menjadi surface runoff, sehingga memperkecil peluang terjadinya genangan di wilayah Kota Jakarta.

\section{KESIMPULAN}

Aplikasi konsep Integrated Urban Water Resources Management (IUWRM) untuk mengatasi masalah krisis sumberdaya air perkotaan sudah merupakan keharusan sebagai solusi pemecahan terhadap masalah terkait dengan pengelolaan sumberdaya air di daerah perkotaan secara terintegrasi, efektif dan efisien. Tidak hanya bagi Kota Jakarta, tetapi juga bagi kota-kota besar lainnya yang mengalami permasalahan serupa dengan Kota Jakarta, seperti Semarang dan Surabaya. Alternatif upaya konservasi air dengan teknik pemanenan air hujan (rain water harvesting) memiliki kemampuan untuk mengatasi permasalahan pengelolaan sumberdaya air sesuai dengan prinsip-prinsip dalam konsep IUWRM.

Berdasarkan kesimpulan di atas, penulis juga merekomendasikan kepada pemerintah (dalam hal ini Pemerintah Daerah Propinsi DKI Jakarta dan Pemerintah Pusat) agar serius dalam menyikapi krisis sumberdaya air yang sudah sedemikian kompleksnya. Upaya konservasi dengan teknik pemanenan air hujan merupakan alternatif pilihan yang patut untuk diimplementasikan. Caranya adalah dengan menghimbau kepada warganya untuk membuat penampungan air hujan di rumah masing-masing. Jika memungkinkan dapat juga memberikan bantuan subsidi kepada warga untuk pembuatan tempat penampungan di rumah masingmasing. Demikian pula himbauan serupa untuk komplek perkantoran, industri, dan sektor usaha. Untuk sektor-sektor ini, mungkin diperlukan suatu regulasi agar mereka terpicu untuk melakukan upaya konservasi air dengan teknik rain water harvesting ini.

Dengan demikian, harapan agar Kota Jakarta yang juga merupakan citra bangsa Indonesia di mata dunia internasional dapat menjadi livable city sekaligus juga menjaga citra sebagai kota masa depan yang bewawasan lingkungan (green city). 


\section{DAFTAR PUSTAKA}

Al Amin, Muhammad Baitullah., Lau, Victor M., Safari, Hanjar., dan Tabarid, Mansur. P. 2008. Teknik Panen hujan dengan Atap Usaha Konservasi Air di Daerah Kering. www BebasBanjir2015.wordpress.com

Ali, Firdaus. 2005. Suatu Konseptual Desain: Deep Tunnel Reservoir, Jakarta Green Plan 2020. Seminar Badan Regulator Pelayanan Air Minum Jakarta, Pan Sari-Pacific Hotel, Jakarta. 12 Desember 2005.

Ali, Firdaus. 2007. Implementasi Konsep IUWRM Untuk Keterpaduan Pengelolaan Sumberdaya Air dan Penanganan Kemacetan Lalu Lintas di Wilayah Metropolitan DKI I Jakarta. Program Studi Teknik Lingkungan, Departemen Teknik Sipil, Fakultas Teknik Universitas Indonesia. Jakarta.

Ali, Firdaus. 2009. Strategi Terpadu Pengelolaan Sumber Daya Air di DKI Jakarta Untuk Mencegah Bencana Ekologi Perkotaan dan Krisis Air. Kemitraan Air Indonesia. www inawater.org
Anonim. 2009. Integrated Water Resources Management. Diktat Kuliah Pengelolaan Sumberdaya Air Terpadu. Fakultas Teknik Pertanian. Institut Pertanian Bogor.

Environment Parliament Watch (EPW) Jakarta. 2007. Potret Lingkungan Hidup Jakarta. www.epwjakarta.multiply.com

Heryani, Nani. 2009. Teknik Panen Hujan: Salah Satu Alternatif Untuk Memenuhi Kebutuhan Air Domestik. Balai Penelitian Agroklimat dan Hidrologi. Departemen Pertanian. Jakarta.

Kompas. 1 September 2008. Kualitas Air di DKI Jakarta. www.kompas.com

Kompas. 10 Mei 2009. Penduduk Bertambah; DKI Krisis Air Bersih. www.kompas.com

Koran Jakarta. 23 Maret 2009. Menangkal Krisis Air di DKI Jakarta. Koalisi Rakyat Untuk Hak Atas Air (KRUHA). www.kruha.org 
